\title{
Kajian Pelaksanaan Kode Etik Aparatur Sipil Negara (ASN) (Studi Kasus Pada Pelaksanaan Kode Etik Aparatur Sipil Negara di Pemerintahan Daerah Kabupaten Ngawi Provinsi Jawa Timur)
}

\author{
Sangrila Puspita Dewi \\ Dosen Ilmu Administrasi Negara, Universitas Soerjo, Jl. Cepu Km.3, Ngawi, 63218 \\ E-mail: sumiaty688@gmail.com
}

\begin{abstract}
To find out how far the application of code of Civil State Apparatus ethics conducted research with descriptive method using closed instrument and sample (n) 18 people of Local Government with case study in District Ngawi East Java Province, found employee perception to ethics organize good enough but need improvement of work quality through performance contracts, training, competence, rewards and sanctions, and performance evaluations.
\end{abstract}

Keywords - : code of ethics; civil servants.

\section{LATAR BELAKANG}

Kelancaran tugas umum pemerintahan dan pembangunan dipengaruhi oleh kesempurnaan pengabdian aparatur negara. Aparatur Sipil Negara (ASN) adalah merupakan unsur aparatur negara yang bertugas memberikan pelayanan yang terbaik, adil dan merata kepada masyarakat. Untuk menjamin tercapainya tujuan pembangunan nasional, diperlukan ASN yang netral, mampu menjaga persatuan dan kesatuan bangsa, profesional dan bertanggungjawab dalam melaksanakan tugas, serta penuh kesetiaan dan ketaatan kepada Pancasila, Undang-undang Dasar 1945, Negara dan Pemerintah Republik Indonesia.

Agar ASN mampu melaksanakan tugasnya sebagaimana tersebut di atas secara berdayaguna dan berhasilguna diperlukan pembinaan. Pembinaan jiwa korps akan berhasil dengan baik apabila diikuti dengan pelaksanaan dan penerapan kode etik dalam kehidupan sehari-hari ASN. Dengan adanya kode etik bagi ASN dimaksudkan sebagai bagian dari upaya meningkatkan kualitas ASN dalam melaksanakan tugas-tugasnya.

Dalam TAP MPR Nomor: VI/MPR/2001 tentang Etika Kehidupan Berbangsa, digariskan kebijakan etika dalam pemerintahan bahwa "Etika pemerintahan mengamanatkan agar penyelenggara negara memiliki rasa kepedulian tinggi dalam memberikan pelayanan kepada publik, siap mundur apabila merasa dirinya telah melanggar kaidah dan sistem nilai atau dianggap tidak mampu memenuhi amanah masyarakat, bangsa, dan negara."

Dalam UU Nomor 43 tahun 1999 tentang perubahan atas UU Nomor 8 tahun 1974 tentang Pokok-pokok Kepegawaian, dalam Pasal 30 antara lain ditegaskan bahwa pembangunan kode etik pegawai negeri sipil akan diatur dalam peraturan pemerintah. Sebagai tindaklanjutPasal 30 tersebut pemerintah telah menerbitkan PP Nomor 42 tahun 2004 tentang Pembinaan Jiwa Korps dan Kode Etik Pegawai Negeri Sipil. Dalam PP Nomor 42 tahun 2004 Pasal 1 antara lain disebutkan "Kode etik pegawai negeri sipil adalah pedoman sikap, tingkah laku, dan perbuatan pegawai negeri sipil di dalam melaksanakan tugasnya dan pergaulan hidup sehari-hari." Nilai-nilai etika tersebut harus diterapkan oleh segenap aparatur pemerintah mulai dari tingkat tertinggi sampai dengan tingkat terendah secara bertanggungjawab.

Dalam Peraturan Presiden Nomor 7 tahun 2005 tentang Rencana Pembangunan Jangka Menengah Nasional tahun 2004-2009 antara lain dimuat program penerapan kepemerintahan yang baik, dengan salah satu kegiatan pokoknya menerapkan nilai-nilai etika aparatur guna membangun budaya kerja yang mendukung produktivitas kerja yang tinggi dalam pelaksanaan tugas dan fungsi penyelenggaraan negara, khususnya dalam rangka pemberian pelayanan umum kepada masyarakat.

Namun, penerapan nilai-nilai etika aparatur pada kenyataannya relatif jauh dari yang diharapkan dari tujuan dan sasaran dikeluarkannya berbagai bentuk peraturan tersebut. Dalam kajian Strategi Pengembangan Etika dalam Pemerintahan (LAN, 2002) disebutkan berbagai permasalahan berkaitan dengan penerapan nilai-nilai etika aparatur, meliputi 3 (tiga) faktor seperti administrasi, instrumen hukum, dan moral perilaku.

Dalam kajian tentang Pengembangan Etika dalam Pelayanan Publik (LAN, 2005) disimpulkan penyelenggaraan pelayanan publik baik di pusat maupun di daerah masih belum menerapkan nilai-nilai etika disebabkan adanya pemahaman yang beragam, tidak didukung kebijakan yang memadai, bertentangan dengan nilai budaya lokal, dan bersifat tidak mengikat dan belum ada strategi yang baku dan memadai dalam pengembangan etika pelayanan publik sehingga etika pelayanan publik yang ada belum mendukung peningkatan kinerja aparatur di pusat dan di daerah.

\section{RUMUSAN MASALAH}

Untuk mengetahui sejauhmana penerapan kode etik aparatur sipil negara khususnya etika dalam berorganisasi sebagaimana dituangkan dalam PP Nomor 42 tahun 2004 perlu dilakukan penelitian kebijakan pelaksanaan kode etik aparatur sipil negara. 
Dengan rumusan masalah yaitu sejauhmana pelaksanaan kode etik aparatur sipil negara di lingkungan pemerintahan Kabupaten Ngawi?

\section{III.KAJIAN PUSTAKA}

Kajian pustaka dilakukan terhadap teori dan landasan kebijakan yang relevan untuk memperoleh gambaran tentang konsep etika dan penerapan kode etik pegawai negeri sipil. Istilah etika berasal dari bahasa Yunani “ethos",yang artinya kebiasaan atau watak (Kumorotomo, 2002:5); atau norma-norma, nilai-nilai, kaidah-kaidah, ukuran-ukuran bagi tingkah laku yang baik (Simorangkir, 2008: 11).

Teori etika berhubungan dengan kajian tentang adat kebiasaan, nilai-nilai, dan norma-norma perilaku manusia yang dianggap baik atau tidak baik. Menurut Sukrisno Agoes dan I Cenik Ardana, (2009: 44-49) bahwa "Teori etika mengalami perkembangan antara lain teori egoisme, utilitarianisme, deontologi (kewajiban), dan teori hak (right theory)". Teori egoisme dan teori utilitarianisme sama-sama menilai baik buruknya suatu tindakan dari akibat, konsekuensi, atau tujuan dari tindakan tersebut. Bila akibat dari suatu tindakan memberikan manfaat entah untuk individu (egoisme) atau untuk banyak orang/kelompok masyarakat (utilitarianisme), maka tindakan itu dikatakan etis.

Sebaliknya, bila akibatnya merugikan maka tindakan itu dikatakan tidak etis. Sedangkan teori deontologi justru mengatakan bahwa etis tidaknya suatu tindakan tidak ada kaitannya sama sekali dengan tujuan, konsekuensi atau akibat dari tindakan tersebut. Suatu perbuatan tidak pernah menjadi baik karena hasilnya baik. Hasil baik tidak pernah menjadi alasan untuk membenarkan suatu tindakan, melainkan hanya karena kita wajib melaksanakan tindakan tersebut demi kewajiban itu sendiri. Sedangkan menurut teori hak, suatu tindakan atau perbuatan dianggap baik bila sesuai dengan hak asasi manusia.

Etika pada hakekatnya merupakan suatu susunan prinsip-prinsip moral dan nilai. Prinsip-prinsip tersebut kemudian diakui dan diterima oleh individu atau suatu kelompok sosial sebagai sesuatu yang mengatur dan mengendalikan tingkah laku serta menentukan hal yang baik dan hal yang buruk untuk dilakukan. Secara konkrit, prinsip-prinsip moral dan nilai tersebut biasanya diwujudkan dalam bentuk suatu kode etik (code of ethic), yaitu suatu aturan, sistem atau standar yang memuat prinsip-prinsip mengelola moralitas dan tingkah laku yang diterima (accepted conduct) dalam suatu lingkungan masyarakat (LAN, 2004: 1011).

The Liang Gie (2001:71) menjelaskan bahwa suatu kode etik merumuskan dalam garis besar berbagai tindakan apa, kelakuan mana, dan sikap bagaimana yang wajib dijalankan atau dihindari oleh para petugas administrasi pemerintahan. Sesuatu kode etik jabatan seringkali perlu pula dilengkapi dengan petunjuk pelaksanaan yang menjelaskan lebih lanjut, menafsirkan secara tegas atau memberikan contoh dari sesuatu asas etis agar dapat diterapkan oleh petugas tanpa keragu-raguan. Sama halnya, yang diungkapkan oleh Dadan Sidqul Anwar (2005: 387-388) yang menjelaskan bahwa penerapan kode etik dalam perspektif new public management (NPM) membutuhkan infrastruktur etik seperti dukungan manajemen dan pedoman pelaksanaannya.

Djohermansyah Djohan dan A. Tadjudin Baso Rum (2001:18) mencontohkan penerapan kode etik di Amerika Serikat, dimana etika jabatan disusun secara tertulis dalam bentuk Code of Ethics yang memuat perbuatan etika pokok yang harus dijadikan pedoman dan pegangan untuk melaksanakan tugas.

Di Indonesia perbuatan etis mendapat wadah dalam UU Nomor 8 tahun 1974 yang telah diperbaharui dengan UU Nomor 43 tahun 1999 tentang Perubahan atas UU Nomor 8 tahun 1974 tentang Pokok-pokok Kepegawaian. UU ini dilengkapi pula dengan PP Nomor 30 tahun 1980 tentang Peraturan Disiplin Pegawai Negeri Sipil. Dengan demikian, melakukan perbuatan etis tidak saja dilandaskan kepada moril tetapi berdasarkan hukum, yang mempengaruhi pula hukuman atas pelanggarannya.

Anwar Supriyadi (2004:4) juga telah menjelaskan nilai-nilai etika yang dikembangkan bukan hanya sekedar untuk menjadi keyakinan pribadi para anggota pegawai negeri (personal values) tetapi diterima dan disepakati menjadi seperangkat norma organisasi (shared values). Etika menjadi acuan atau pedoman dalam bersikap dan bertindak dari seluruh jajaran organisasi pemerintahan dan pelanggaran atasnya membawa konsekuensi moral.

Setiap anggota aparatur dituntut untuk mentaatinya dengan sadar dan penuh disiplin. Yang melanggar disiplin dapat dikenakan sanksi administratif sesuai dengan jenis dan sifat pelanggaran (penurunan pangkat dan sejenis). Pegawai yang taat atas etika mendapatkan ganjaran, tanda penghargaan dan sebagainya.

Dewasa ini, pemerintah telah menetapkan PP Nomor 42 tahun 2004 tentang Pembinaan Jiwa Korps dan Kode Etik Pegawai Negeri Sipil, memuat antara lain (1) Etika dalam bernegara; (2) etika dalam berorganisasi; (3) etika dalam bermasyarakat; (4) etika terhadap diri sendiri; dan (5) etika terhadap sesama pegawai negeri sipil. Kode etik tersebut diatas, harus diterapkan oleh segenap aparatur pemerintah mulai dari tingkat tertinggi sampai dengan tingkat terendah secara bertanggungjawab.

Mengingat luasnya cakupan kode etik Aparatur Sipil Negara, maka dilakukan pembatasan kajian pada etika dalam berorganisasi yang meliputi: (a) melaksanakan tugas dan wewenang sesuai ketentuan yang berlaku; (b) menjaga informasi yang bersifat rahasia; (c) melaksanakan setiap kebijakan yang ditetapkan oleh pejabat yang berwenang; (d) membangun etos kerja untuk meningkatkan kinerja organisasi; (e) menjalin kerjasama secara kooperatif dengan unit kerja lain yang terkait dalam rangka pencapaian tujuan; (f) memiliki kompetensi dalam pelaksanaan tugas; (g) patuh dan taat terhadap standar operasional dan tata kerja; (h) mengembangkan pemikiran secara kreatif dan inovatif dalam rangka peningkatan kinerja organisasi; (i) berorientasi pada upaya peningkatan kualitas kerja. 


\section{IV.METODE PENELITIAN}

Penelitian menggunakan metode deskriptif dengan case-studydi Pemerintah Daerah Kabupaten Ngawi. Penelitian menggunakan sampel yang diambil dengan teknik purposive sampling yaitu penentuan sampel dengan tujuan tertentu karena dari sampel yang dipilih dapat diperoleh data yang diperlukan (Sugiyono, 1998:60). Pengumpulan data primer menggunakan kuesioner tertutup. Sedangkan, data dianalisis dengan menggunakan teknik kualitatif.

\section{HASIL DAN PEMBAHASAN}

Hasil penelitian (lihat tabel dalam lampiran) menunjukkan persepsi pegawai terhadap pelaksanaan kode etik pegawai negeri di Pemerintah Daerah Kabupaten Ngawidalam 9 (sembilan) aspek etika dalam berorganisasi. Data selanjutnya dianalisis dengan memberikan penilaian cukup baik apabila kecenderungan data (di atas 50\%) pada pernyataan positif "selalu" dan "sering", sedangkan bila berada pada pernyataan negatif "kadang-kadang", atau "tidak pernah" maka dinilai kurang baik.

Pertama, dalam aspek melaksanakan tugas dan wewenang sesuai ketentuan yang berlaku (butir A.1-9) yaitu sebagai berikut:

1) Dalam melaksanakan tugas dan wewenang, responden umumnya (89\%) menyatakan selalu didasarkan kebijakan/peraturan tentang organisasi dan tata kerja yang memuat tugas pokok dan fungsi. Berarti persepsi pegawai terhadap pelaksanaan tugas dan wewenang berdasarkan kebijakan atau peraturan, cukup baik.

2) Dalam melaksanakan tugas dan wewenang, responden umumnya (74\%) menyatakan selalu didasarkan pada uraian tugas (job description) yang merupakan penjabaran dari tugas pokok dan fungsi. Berarti persepsi pegawai terhadap pelaksanaan tugas dan wewenang berdasarkan uraian tugas, cukup baik.

3) Dalam melaksanakan tugas dan wewenang, sebagian responden (55\%) menyatakan selalu didasarkan pedoman tata kerja untuk mengetahui tingkat keberhasilan. Berarti persepsi pegawai terhadap pelaksanaan tugas dan wewenang berdasarkan pedoman tata kerja, cukup baik.

4) Dalam melaksanakan tugas dan wewenang, sebagian responden (33\%) menyatakan kadang-kadang didasarkan pada kontrak kinerja. Berarti persepsi pegawai terhadap pelaksanaan tugas dan wewenang berdasarkan kontrak kinerja, masih kurang baik. Oleh karena itu, perlu peningkatan kontrak kinerja dalam melaksanakan tugas dan wewenang.

5) Mengenai sosialisasi peraturan atau kebijakan yang mendasari pelaksanaan tugas, sebagian responden (55\%) menyatakan selalu diadakan sosialisasi kepada pegawai. Berarti persepsi pegawai terhadap sosialisasi peraturan/kebijakan pelaksanaan tugas, cukup baik.

6) Mengenai tingkat pemahaman pegawai terhadap peraturan/kebijakan pelaksanaan tugas dan wewenang, sebagian (44\%) responden menyatakan selalu, dan sebagian lainnya (44\%) menyatakan seringkali dapat dipahami. Berarti persepsi pegawai terhadap pemahaman peraturan/kebijakan pelaksanaan tugas dan wewenang, cukup baik.

7) Terkait dengan pelaksanaan peraturan/kebijakan terkait tugas dan wewenang, responden umumnya (72\%) menyatakan selalu melaksanakannya dengan baik dan benar. Berarti persepsi pegawai terhadap pelaksanaan peraturan/kebijakan tugas dan wewenang, cukup baik.

8) Terkait dengan evaluasi pelaksanaan tugas dan wewenang, sebagian responden (50\%) menyatakan selalu dilakukan evaluasi berkala; Berarti persepsi pegawai terhadap evaluasi pelaksanaan tugas dan wewenang belum baik. Oleh karenanya, diperlukan peningkatan evaluasi pelaksanaan tugas dan wewenang.

9) Terkait dengan hasil evaluasi pelaksanaan tugas dan wewenang, sebagian responden (56\%) menyatakan selalu digunakan untuk perbaikan pelaksanaan tugas dan wewenang masa yang akan datang. Berarti persepsi pegawai terhadap pemanfaatan hasil evaluasi pelaksanaan tugas dan wewenang untuk perbaikan pelaksnaan tugas dan wewenang cukup baik.

Kedua, dalam aspek menjaga informasi yang bersifat rahasia (butir B.1-5) yaitu sebagai berikut:

1) Terkait dengan bentuk pengaturan menjaga informasi bersifat rahasia, responden umumnya (78\%) menyatakan selalu diatur dalam peraturan atau kebijakan tertentu. Berarti persepsi pegawai terhadap bentuk pengaturan menjaga informasi bersifat rahasia dalam peraturan atau kebijakan tertentu cukup baik.

2) Mengenai kemampuan pegawai dalam menjaga informasi kantor yang bersifat rahasia, responden umumnya (72\%) menyatakan pegawai selalu dapat menjaga informasi kantor yang bersifat rahasia. Berarti persepsi pegawai terhadap kemampuan menjaga informasi bersifat rahasia cukup baik.

3) Terkait dengan tempat penyimpanan dokumen yang bersifat rahasia, responden umumnya (72\%) menyatakan selalu disimpan pada tempat tertentu secara baik. Berarti persepsi pegawai terhadap penyimpanan dokumen bersifat rahasia pada tempat tertentu cukup baik.

4) Mengenai penghargaan terhadap pegawai dalam menjaga informasi rahasia, responden umumnya (67\%) menyatakan kadang-kadang diberi penghargaan. Berarti persepsi pegawai terhadap penghargaan dalam menjaga informasi rahasia kurang baik. Oleh karena itu, perlu upaya meningkatkan pemberian penghargaan terhadap pegawai dalam menjaga informasi rahasia; dan

5) Terkait dengan pemberian sanksi terhadap pegawai yang tidak dapat menjaga informasi rahasia, sebagian responden (39\%) menyatakan selalu diberi sanksi. Berarti persepsi pegawai terhadap pemberian sanksi bagi pegawai yang tidak dapat menjaga informasi rahasia kurang baik. Oleh karena itu, perlu ketegasan pemberian sanksi bagi pegawai yang tidak dapat menjaga informasi rahasia sesuai peraturan yang berlaku. 
Ketiga, dalam aspek melaksanakan setiap kebijakan yang ditetapkan oleh pejabat yang berwenang (butir C.1-6), yaitu sebagai berikut:

1) Terkait dengan sosialisasi kebijakan, responden umumnya (67\%) menyatakan selalu ada sosialisasi kebijakan kepada pegawai. Berarti persepsi pegawai terhadap sosialisasi kebijakan cukup baik.

2) Terkait dengan tingkat pemahaman pegawai terhadap kebijakan, sebagian responden (39\%) menyatakan selalu, dan sebagian responden lainnya (39\%) menyatakan seringkali memahami kebijakan yang akan dilaksanakan. Berarti persepsi pegawai terhadap pemahaman kebijakan cukup baik.

3) Terkait dengan pelaksanaan kebijakan, responden umumnya (72\%) menyatakan selalu didasarkan pada mekanisme tertentu sebagai acuan kerja. Berarti persepsi pegawai terhadap pelaksanaan kebijakan berdasarkan mekanisme acuan kerja cukup baik.

4) Terkait dengan pelaksanaan kebijakan, sebagian responden (55\%) menyatakan selalu ada instrumen yang dijadikan acuan. Berarti persepsi pegawai terhadap pelaksanaan kebijakan berdasarkan instrumen yang dijadikan acuan cukup baik.

5) Terkait dengan kemampuan pegawai dalam melaksanakan kebijakan, umumnya responden (72\%) menyatakan seringkali setiap kebijakan diselesaikan tepat waktu dan berkualitas. Berarti persepsi pegawai terhadap terhadap kemampuan melaksanakan kebijakan secara tepat waktu dan berkualitas cukup baik.

6) Terkait dengan evaluasi pelaksanaan kebijakan, sebagian responden (50\%) menyatakan seringkali dilakukan evaluasi berkala. Berarti persepsi pegawai terhadap evaluasi pelaksanaan kebijakan kurang baik. Oleh karena itu, perlu dilakukan peningkatan evaluasi berkala terhadap pelaksanaan kebijakan yang ditetapkan oleh pejabat yang berwenang.

Keempat, dalam aspek membangun etos kerja untuk meningkatkan kinerja organisasi (butir D.1-9) yaitu sebagai berikut :

1) Responden umumnya (94\%) menyatakan selalu didasari pemahaman nilai-nilai organisasi seperti visi dan misi instansi. Berarti persepsi pegawai terhadap pemahaman nilai-nilai seperti visi, misi organisasi cukup baik.

2) Sebagian responden (56\%) menyatakan pimpinan kadang-kadang berusaha menggugah semangat dan menggerakkan bawahan dalam membangun etos kerja. Berarti persepsi pegawai terhadap upaya pimpinan menggugah semangat dan menggerakkan bawahan cukup baik.

3) Sebagian responden (67\%) menyatakan pimpinan selalu memperhatikan kesejahteraan bawahan. Berarti persepsi pegawai terhadap pimpinan dalam memperhatikan kesejahteraan bawahan cukup baik.

4) Terkait dengan pola karier yang dilaksanakan, sebagian responden (44\%) menyatakan sering dapat membangun etos kerja. Berarti persepsi pegawai terhadap pola karier yang dilaksanakan kurang baik. Oleh karena itu, perlu peningkatan pola karier dalam membangun etos kerja.

5) Terkait dengan penghargaan dan hukuman yang dilaksanakan, sebagian responden (55\%) menyatakan kadang-kadang sesuai peraturan perundangan yang berlaku. Berarti persepsi pegawai terhadap penghargaan dan hukuman yang dilaksanakan sesuai peraturan yang berlaku kurang baik. Oleh karena itu, perlu peningkatan penghargaan dan hukuman yang dilaksanakan sesuai peraturan yang berlaku.

6) Belajar bersama secara berkala yang dilakukan oleh anggota organisasi/unit kerja, responden umumnya (61\%) menyatakan dapat membangun etos kerja. Berarti persepsi pegawai terhadap belajar bersama secara berkala oleh anggota organisasi cukup baik.

7) Terkait dengan bekerja secara tim dalam organisasi/unit kerja, responden umumnya menyatakan (72\%) dapat membangun etos kerja. Berarti persepsi pegawai terhadap bekerja secara tim cukup baik

8) Terkait dengan disiplin yang diterapkan sesuai dengan peraturan perundangan yang berlaku, responden umumnya (61\%) menyatakan selalu dapat membangun etos kerja. Berarti persepsi pegawai terhadap disiplin yang diterapkan cukup baik.

9) Untuk mengetahui tingkat keberhasilan dalam membangun etos kerja, sebagian responden (44\%) menyatakan seringkali dilakukan evaluasi berkala. Berarti persepsi pegawai terhadap evaluasi tingkat keberhasilan membangun etos kerja kurang baik. Oleh karena itu, perlu peningkatan evaluasi tingkat keberhasilan membangun etos kerja.

Kelima, dalam aspek menjalin kerjasama secara kooperatif dengan unit kerja lain yang terkait dalam rangka pencapaian tujuan (butir E.1-7), yaitu sebagai berikut:

1) Dalam menjalin kerjasama dengan unit kerja lain, responden umumnya (61\%) menyatakan selalu didasarkan pada peraturan/kebijakan berupa kesepakatan bersama yang harus ditaati. Berarti persepsi pegawai dalam menjalin kerjasama dengan unit lain cukup baik.

2) Sebagian responden menyatakan (56\%) selalu ada mekanisme (sistem dan prosedur) yang dijadikan acuan dalam operasional/ pelaksanaan. Berarti persepsi pegawai terhadap mekanisme yang dijadikan acuan pelaksanaan kerjasama dengan unit lain cukup baik

3) Mengenai upaya yang dilakukan dalam membangun kerjasama, sebagian responden (50\%) menyatakan selalu diawali dengan adanya jejaring kerja (net working). Berarti persepsi pegawai terhadap jejaring kerja kurang baik. Oleh karena itu, perlu peningkatan jejaring kerja (net working) dengan unit kerja terkait.

4) Terkait kesesuaian tugas dan wewenang dalam menjalin kerjasama, sebagian responden (50\%) menyatakan selalu dilakukan sesuai dengan tugas dan wewenang. Berarti persepsi pegawai terhadap kesesuaian tugas dan wewenang dalam menjalin kerjasama kurang baik. Oleh karena itu, dalam menjalin kerjasama perlu memperhatikan kesesuaian tugas dan wewenang. 
5) Terkait dengan kerjasama yang dilakukan dengan unit lain, sebagian responden (50\%) menyatakan selalu berjalan secara efisien dan efektif. Berarti persepsi pegawai terhadap kerjasama dengan unit lain secara efisien dan efektif kurang baik. Oleh karena itu, perlu diupayakan kerjasama yang saling menguntungkan kedua belah pihak.

6) Terkait dengan manfaat kerjasama yang dilakukan, sebagian responden (56\%) menyatakan selalu bermanfaat meningkatkan kinerja organisasi. Berarti persepsi pegawai terhadap manfaat kerjasama yang dilakukan cukup baik.

7) Mengenai evaluasi pelaksanaan kerjasama dengan unit lain, sebagian responden (39\%) menyatakan selalu, dan sebagian responden lainnya (39\%) menyatakan seringkali dilakukan evaluasi secara berkala. Berarti persepsi pegawai terhadap evaluasi berkala pelaksanaan kerjasama cukup baik.

Keenam, dalam aspek memiliki kompetensi dalam pelaksanaan tugas (butir F.1-6), yaitu sebagai berikut:

1) Sebagian responden (56\%) menyatakan ada standar kompetensi yang ditetapkan berdasarkan peraturan. Pemerintah telah mengeluarkan Keputusan Kepala Badan Kepegawaian Negara Nomor 46A Tahun 2003 tentang Pedoman Penyusunan Standar Kompetensi Jabatan Struktural Pegawai Negeri Sipil. Berarti persepsi pegawai terhadap standar kompetensi berdasarkan peraturan cukup baik.

2) Mengenai sosialisasi standar kompetensi, sebagian kecil responden (39\%) menyatakan ada sosialisasi standar kompetensi; Berarti persepsi pegawai terhadap sosialisasi standar kompetensi kurang baik. Oleh karena itu, perlu dilakukan upaya meningkatkan sosialisasi standar kompetensi bagi pegawai.

3) Terkait dengan persyaratan untuk menduduki jabatan tertentu, sebagian responden (33\%) menyatakan kadang-kadang diadakan uji kelayakan sesuai dengan kompetensi yang dibutuhkan. Berarti persepsi pegawai terhadap uji kelayakan sesuai dengan kompetensi yang dibutuhkan kurang baik. Oleh karena itu, perlu dilakukan upaya meningkatkan uji kelayakan sesuai kompetensi untuk menduduki jabatan tertentu.

4) Mengenai kesesuaian jabatan dan kompetensi, sebagian kecil responden (38\%) menyatakan ada kesesuaian antara kompetensi dan jabatan yang dipangku. Berarti kesesuaian jabatan dan kompetensi kurang baik. Oleh karena itu, perlu upaya meningkatkan kesesuaian antara kompetensi dan jabatan yang dipangku melalui pengembangan pegawai dalam diklat dan kursus.

5) Terkait dengan upaya peningkatan kompetensi pegawai sesuai dengan bidang tugas, sebagian responden (56\%) menyatakan selalu diadakan pengembangan pegawai seperti diklat sesuai dengan jabatan. Berarti pengembangan pegawai seperti diklat sesuai jabatan cukup baik

6) Terkait dengan evaluasi pelaksanaan standar kompetensi, sebagian responden (39\%) menyatakan seringkali dilakukan evaluasi secara berkala. Berarti evaluasi pelaksanaan standar kompetensi kurang baik. Oleh karena itu perlu peningkatan evaluasi pelaksanaan standar kompetensi secara berkala.

Ketujuh, dalam aspek patuh dan taat terhadap standar operasional dan tatakerja (butir G.1-7), yaitu sebagai berikut:

1) Terkait dengan bentuk standar operasional prosedur (SOP) dan tatakerja yang dijadikan acuan dalam melaksanakan tugas, hanya sebagian responden $(50 \%)$ menyatakan seringkali dituangkan dalam bentuk peraturan/kebijakan. Berarti persepsi pegawai terhadap SOP yang dituangkan dalam bentuk peraturan/kebijakan masih kurang baik. Oleh karena itu perlu peningkatan bentuk SOP kedalam peraturan/kebijakan.

2) Terkait dengan sosialisasi SOP sebelum dilaksanakan, hanya sebagian responden (50\%) menyatakan dilakukan sosialisasi SOP kepada seluruh pegawai. Berarti persepsi pegawai terhadap sosialisasi SOP masih kurang baik. Oleh karena itu perlu peningkatan sosialisasi SOP kepada seluruh pegawai.

3) Terkait dengan tingkat pemahaman pegawai terhadap SOP, hanya sebagian responden (48\%) menyatakan pegawai selalu memahami SOP yang disosialisasikan. Berarti persepsi pegawai terhadap pemahaman SOP masih kurang baik. Oleh karena itu, perlu peningkatan pemahaman SOP melalui sosialisasi SOP terhadap seluruh pegawai.

4) Terkait dengan kemampuan pegawai dalam melaksanakan SOP, sebagian responden (55\%) menyatakan selalu dapat dilaksanakan dengan baik. Berarti persepsi pegawai terhadap kemampuan melaksanakan SOP cukup baik.

5) Terkait dengan penghargaan atas kepatuhan dan ketaatan terhadap pelaksanaan SOP, sebagian kecil responden (38\%) menyatakan selalu diberikan penghargaan. Berarti persepsi pegawai terhadap penghargaan atas kepatuhan dan ketaatan dalam melaksanakan SOP masih kurang baik. Perlu peningkatan pemberian penghargaan atas kepatuhan dan ketaatan terhadap pelaksanaan SOP.

6) Terkait dengan pelanggaran terhadap SOP, sebagian responden (50\%) menyatakan kadang-kadang diberikan sanksi. Berarti persepsi pegawai terhadap sanksi atas pelanggaran SOP kurang baik. Perlu peningkatan upaya pemberian sanksi sesuai peraturan atas pelanggaran SOP.

7) Terkait dengan evaluasi pelaksanaan SOP, sebagian responden (33\%) menyatakan seringkali, dan sebagian responden lainnya (33\%) menyatakan kadang-kadang dilakukan evaluasi secara berkala. Berarti persepsi pegawai terhadap evaluasi pelaksanaan SOP kurang baik. Perlu peningkatan evaluasi pelaksanaan SOP.

Kedelapan, dalam aspek mengembangkan pemikiran secara kreatif dan inovatif dalam rangka peningkatan kinerja organisasi (butir H.1-6) yaitu sebagai berikut:

1) Terkait dengan kebijakan pimpinan, sebagian responden (50\%) menyatakan selalu dapat mendorong pengembangan pemikiran kreatif dan inovatif. Berarti persepsi pegawai terhadap kebijakan dalam mendorong pemikiran kreatif dan inovatif kurang baik. Pimpinan perlu meningkatkan kebijakan pengembangan pemikiran kreatif dan inovatif. 
2) Terkait dengan kelompok diskusi yang dibangun dalam organisasi, sebagian responden (50\%) menyatakan selalu dapat mengembangkan pemikiran secara kreatif dan inovatif. Berarti persepsi pegawai terhadap kelompok diskusi kurang baik. Perlu peningkatan upaya membangun kelompok diskusi dalam organisasi.

3) Terkait dengan kebebasan yang ada dalam organisasi, hanya sebagian responden (44\%) menyatakan selalu dapat mendorong pegawai untuk menyampaikan pemikiran secara kreatif dan inovatif kepada pimpinan. Berarti persepsi pegawai terhadap kebebasan menyampaikan pemikiran kreatif dan inovatif masih kurang baik. Perlu upaya meningkatkan kebebasan menyampaikan pemikiran kreatif dan inovatif.

4) Sebagian responden (39\%) menyatakan selalu, dan sebagian responden lainnya (39\%) menyatakan pegawai seringkali berusaha mencari cara kerja baru yang terbaik dalam meningkatkan kinerja organisasi. Berarti persepsi pegawai terhadap upaya mencari cara kerja baru yang terbaik cukup baik

5) Sebagian responden (45\%) menyatakan pegawai seringkali mempunyai kemauan tinggi melaksanakan tugas tanpa menunggu perintah pimpinan. Berarti persepsi pegawai terhadap kemauan melaksanakan tugas tanpa menunggu perintah kurang baik. Perlu upaya peningkatan kemauan melaksanakan tugas tanpa menunggu perintah pimpinan

6) Sebagian responden (39\%) menyatakan selalu, dan sebagian responden lainnya (39\%) menyatakan pegawai seringkali mampu dengan cepat mempelajari sesuatu yang baru dalam meningkatkan kinerja organisasi. Berarti persepsi pegawai terhadap kemampuan cepat mempelajari sesuatu yang baru cukup baik.

Kesembilan, dalam aspek berorientasi pada upaya peningkatan kualitas kerja (butir I.1-6) yaitu sebagai berikut:

1) Terkait dengan kebijakan yang ada dalam organisasi, responden umumnya (78\%) menyatakan selalu berorientasi pada upaya peningkatan kualitas kerja. Berarti persepsi pegawai cukup baik terhadap kebijakan berorientasi upaya peningkatan kualitas kerja cukup baik.

2) Sebagian responden (38\%) menyatakan selalu, dan sebagian responden lainnya (38\%) menyatakan sering ada instrumen (seperti kontrak kinerja) yang digunakan dalam upaya peningkatan kualitas kerja. Berarti persepsi pegawai terhadap instrumen seperti kontrak kinerja memang kurang baik. Perlu upaya penggunaan instrumen seperti kontrak kinerja dalam upaya meningkatkan kualitas kerja.

3) Terkait dengan pengembangan pegawai (melalui kursus/ diklat), hanya sebagian responden (44\%) menyatakan seringkali dilakukan dalam upaya peningkatan kualitas kerja. Berarti pengembangan pegawai melalui kursus/diklat masih kurang baik. Perlu upaya meningkatkan pengembangan pegawai melalui kursus/diklat.

4) Sebagian responden (50\%) menyatakan pimpinan atau pegawai seringkali mendengarkan atau memperhatikan kritik/saran serta ide yang lebih baik dalam upaya peningkatan kualitas kerja. Berarti persepsi kemauan pegawai dalam mendengarkan atau memperhatikan kritik/saran serta ide, masih rendah. Perlu upaya meningkatkan kemauan pegawai mendengarkan ataumemperhatikan kritik atau saran serta ide.

5) Terkait dengan bekerja secara tim dalam organisasi, responden umumnya (61\%) menyatakan dapat meningkatkan kualitas kerja. Berarti persepsi pegawai terhadap bekerja secara tim dalam organisasi cukup baik.

Terkait dengan perlakuan secara adil terhadap anggota organisasi, responden umumnya (72\%) menyatakan meningkatkan kualitas kerja. Berarti persepsi pegawai terhadap perlakuan adil bagi anggota organisasi cukup baik.

\section{VI.KESIMPULAN DAN SARAN}

\section{A. Kesimpulan}

Disimpulkan penerapan kebijakan kode etik khususnya etika dalam berorganisasi meliputi 9 (sembilan) aspek berikut:

1) Melaksanakan tugas dan wewenang sesuai ketentuan yang berlaku telah dilaksanakan, sedangkan pelaksanaan tugas dan wewenang berdasarkan kontrak kinerja kurang diterapkan;

2) Menjaga informasi yang bersifat rahasia telah dilaksanakan, sedangkan penghargaan dalam menjaga atau sanksi bila tidak menjaga informasi yang bersifat rahasia kurang diterapkan;

3) Melaksanakan setiap kebijakan yang ditetapkan oleh pejabat yang berwenang telah dilaksanakan, sedangkan evaluasi terhadap kebijakan yang ditetapkan pimpinan kurang diterapkan;

4) Membangun etos kerja untuk meningkatkan kinerja organisasi telah dilaksanakan, sedangkan pola karier, penghargaan dan hukuman, serta evaluasi tingkat keberhasilan membangun etos kerja kurang diterapkan;

5) Menjalin kerjasama secara kooperatif dengan unit kerja lain yang terkait dalam rangka pencapaian tujuan telah dilaksanakan;

6) Memiliki kompetensi dalam pelaksanaan tugas telah dilaksanakan, sedangkan sosialisasi standar kompetensi, uji kelayakan sesuai kompetensi yang dibutuhkan dalam menduduki jabatan, kesesuaian kompetensi dengan jabatan yang dipangku serta evaluasi standar kompetensi kurang dilakukan;

7) Kepatuhan dan ketaatan terhadap standar operasional dan tata kerja telah dilaksanakan, sedangkan penghargaan terhadap pelaksanaan SOP dan sanksi terhadap pelanggaran SOP kurang diterapkan;

8) Mengembangkan pemikiran secara kreatif dan inovatif dalam rangka peningkatan kinerja organisasi sudah dilaksanakan, dimana kebijakan dalam mendorong pemikiran kreatif dan inovatif, kelompok diskusi, dan kemauan melaksanakan tugas tanpa menunggu perintah kurang diterapkan; 
Website : http://sosial.unmermadiun.ac.id/index.php/sosial

9) Berorientasi pada upaya peningkatan kualitas kerja telah dilaksanakan, sedangkan instrumen kontrak kinerja, pengembangan pegawai melalui diklat/kursus, dan kemauan mendengar/memperhatikan kritik/saran serta ide kurang diterapkan.

\section{B. Saran}

Berdasarkan hasil penelituan di atas, maka penulisdapat memberikan saran bahwa perlu meningkatkan etika dalam berorganisasi dengan melakukan upaya sebagai berikut:

1) Meningkatkan pelaksanaan tugas dan wewenang berdasarkan kontrak kinerja.

2) Pemberian penghargaan dalam menjaga informasi rahasia, dan sanksi bila tidak menjaga informasi rahasia

3) Meningkatkan evaluasi kebijakan yang ditetapkan pimpinan.

4) Membangun pola karier, dan meningkatkan penghargaan dan hukuman sesuai peraturan, serta evaluasi tingkat keberhasilan etos kerja

5) Meningkatkan sosialisasi standar kompetensi, uji kelayakan sesuai kompetensi yang dibutuhkan dalam menduduki jabatan, kesesuaian kompetensi dengan jabatan yang dipangku serta evaluasi standar kompetensi.

6) Pemberian penghargaan terhadap pelaksanaan maupun sanksi terhadap pelanggaran SOP.

7) Mengembangkan pemikiran kreatif dan inovatif, kelompok diskusi, dan kemauan melaksanakan tugas tanpa menunggu perintah.

8) Meningkatkan instrumen kontrak kinerja, mengembangkan pegawai melalui diklat/kursus, dan kemauan mendengar/ memperhatikan kritik/saran serta ide yang lebih baik dalam upaya peningkatan kualitas kerja.

\section{DAFTAR PUSTAKA}

Buku :

Anwar Supriyadi, Mei 2004. Etika Birokrasi dalam mewujudkan Good Governance. Jurnal STIA LAN Jakarta Vol. 3 No. 1;

Dadan Sidqul Anwar, 2006. Ethical Management in the Public Service Management an International Phenomenon. Bunga Rampai Administrasi Publik. Jakarta. LAN;

Djohermansyah Djohan dan A. Tadjudin Baso Rum, 2001. Etika Pemerintahan. Jakarta. Universitas Terbuka;

Lembaga Administrasi Negara, 2005. Kajian tentang Pengembangan Etika dalam Pelayanan Publik. Jakarta. LAN;

2004. Etika dalam Penyelenggaraan Negara. Jakarta. LAN;

2002. Kajian Strategi Pengembangan Etika dalam Pemerintahan. Jakarta. LAN;

O.P. Simorangkir, 1978. Etika dalam Jabatan. Jakarta. Yagrat;

Sugiyono, 1998. Metode Penelitian Administrasi, Bandung. Alfabeta;

Sukrisno Agoes dan I Cenik Ardana, 2009, Etika Bisnis dan Profesi. Jakarta. Penerbit Salemba Empat;

The Liang Gie, 2001. Etika Administrasi Pemerintahan, Cet. 6, Jakarta. Universitas Terbuka;

Wahyudi Kumorotomo, 2002. Etika Administrasi Negara, Cet. 5, Jakarta. PT. RajaGrafindo Persada.

Peraturan :

Ketetapan MPR-RI Nomor VI/MPR/2001 tentang Etika Kehidupan Bernegara;

Peraturan Pemerintah Nomor 42 tahun 2004 tentang Pembinaan Jiwa Korps dan Kode Etik Pegawai Negeri Sipil. 